\title{
DEBATES
}

\section{Becoming untimely: towards a postcolonial regime of aesthetics}

\author{
Tornando-se extemporâneo: em direção a um regime estético pós- \\ colonial
}

\section{Rohan Kalyan}

\begin{abstract}
This essay is an inquiry into the possibility of a postcolonial regime of aesthetics. Through an analysis of a curated set of theoretical and artistic texts (coming primarily from South Asia) it argues that such an aesthetic regime might contribute to an apprehension of the productive ambivalence at the heart of political modernity, both on the subcontinent and in other regions around the planet. Works in these artistic genres and intellectual milieus foreground the haunting, split legacies of colonialism and empire in the political present. They make postcolonial ambivalence a productive site of cultural mediation, using it to interrogate the invention of national imaginaries that were often a response to the imposition of colonial and imperial power.
\end{abstract}

\section{Keywords}

Postcolonialism; Politics; Theory; Aesthetics; Difference.

\section{Resumo}

Este trabalho é uma investigação sobre a possibilidade de um regime estético pós-colonial. Por meio de uma análise de um conjunto curado de textos teóricos e artísticos (vindos principalmente do sul da Ásia), argumenta-se que tal regime estético pode contribuir para uma apreensão da ambivalência produtiva no cerne da modernidade política, tanto no subcontinente como em outras regióes em todo o planeta. Obras nesses gêneros artísticos e meios intelectuais trazem à tona os legados assombrosos e divididos do colonialismo e do império no presente político. Eles fazem da ambivalência pós-colonial um local produtivo de mediaçáo cultural, usando-a para questionar a invenção de imaginários nacionais que muitas vezes foram uma resposta à imposição de violência colonial e imperial.

\section{Palavras-chave}

Pós-colonialismo; Política; Teoria; Estética; Diferença. 


\section{Introduction}

"The narrow epistemic violence of imperialism gives us an imperfect allegory of the general violence that is the possibility of an episteme."

Gayatri Spivak (1988, p. 28)

"It behooves philosophy not to be modern at any price, nor yet to be timeless, but to extricate from modernity something that Nietzsche called the untimely, which belongs to modernity, but which must also be turned against it - in favor, I hope, of a future time?."

Gilles Deleuze (1983, p. 55)

Born from a history of partitions, displacements and erasures, "postcolonial" genres of art and thought project an insurgent, liberatory politics aimed at de-centering Europe/ the West, not merely as imperial power but as "universal" episteme (SPIVAK, 1999; CHAKRABARTY, 2000). This has often entailed a disfiguring, cutting, or repartitioning of concepts like the modern, the human, the nation, and more recently, the global. Such a cutting logic carries with it a potential danger: a reversion to essentialism, a slippage into cultural relativism, patriarchal ethno-nationalism, or worse. But the act of cutting, of re-partitioning, is also a creation; it is a repetition (for it is not the first blow) which creates something different and new. Postcolonial expression becomes part of an impulse to cut back and retrace the alterity of the present to its historical roots - the colonial encounter-in order to stop playing what Frantz Fanon (2004 [1961], p. 236) once called "the European game". The postcolonial prerogative, Fanon and others have insisted, is to "look for something else." Yet, what if this "something else" becomes a practice of expression that is no less an act of liberation, of empowerment, of anti-colonial agency, than a dark foreshadowing of postcolonial violence to come?

If one wanted to argue that there was a distinct style to postcolonial thought, that is, an aesthetics of the postcolonial, how would one go about theorizing its specificity? What would be the purpose of such a line of inquiry? What would be the stakes? And how would a thinking of the political become enabled or limited in a specifically postcolonial regime of aesthetics? ${ }^{1}$

\footnotetext{
${ }^{1}$ I use the adjective "specific" to describe the postcolonial rather than "particular" or "singular" for two reasons. First, I want to situate this discussion of postcolonial aesthetics outside the usual universal/ particular binary that such debates usually get trapped in. Such a move is all the more urgent when the idea of the universal continues to be sutured to a mystified image of "the West," or "Europe," as a "hyperreal" space (CHAKRABARTY, 2000). Second, I use the figure of "the specific" in reference to
} 
Thinking about postcolonial thought stylistically, that is, putting an aesthetic criterion to the ways in which the experience of coloniality and empire becomes organized, distributed and partitioned in particular texts, brings politics and history into a critical intersection with the arts. For art and aesthetic expression, broadly conceived, play a significant and complex role in how socio-political and/or cultural worlds become reproduced and perceptually organized, that is, constituted as "communities of sense" and sense-making (SHAPIRO, 2018). The question of what is postcolonial thinking and artistic expression becomes inextricable from larger questions about political community, inclusion and exclusion, inequality and subjectivation (RANCIERE, 2006). In this essay I engage with postcolonial genres of theory and art coming primarily from South Asia, for reasons owing to my own background specialization than to anything specific about this region itself. In other words, for all the historical contingencies and peculiarities that make up South Asia's political cultures and communities, someone else, with a focus on a different region, might make a similar argument about another colonial/ postcolonial context. My general hypothesis is that works from these geo-historically diverse artistic genres and intellectual milieus might be distinguished by the way in which they foreground the haunting, split legacies of colonial pasts and neo-colonial presents in constituting political modernity. And at times they focus on the productive ambivalence of political cultures and communities produced and reproduced in response to the imposition of colonial power in its diverse forms. ${ }^{2}$ This focus on ambivalence is performed in the interest of re-partitioning our sense of the political itself, that is, the political as the

the work of Marxian theorist Henri Lefebvre, particularly his essay, "The specificity of the city," where he links specificity in modern urban life to the heterogeneous practices and relationships that shape the practical and visceral experience of everyday politics. Lefebvre (1996, p. 100) relates the urban sensorium to macro-political forces and structures, though not directly-as in orthodox superstructure/base models_-but "through mediations". Here, we might think of the political as a specific strategy for mediating (that is, translating and transforming) between what Lefebvre (1996, p. 101) called the "far order" and the "near order". In the colonial situation, however, the distance of the far order from everyday, ordinary (common) sensory life is not solely of a political nature but a cultural one as well. As I argue elsewhere, this doubling/ duplicity of relations and imaginations of distance and proximity (in both space and time) structures the complex hauntology of the postcolonial condition (KALYAN, 2017).

${ }^{2}$ By “imposition and response," I am referring to Robbie Shilliam's way of characterizing the productive ambivalence of the colonial encounter and its aftermath in most of the world. For more see: "Imposition and Response: an illustrated video with Dr. Robbie Shilliam" (KALYAN, 2020). 
distribution of common and uncommon sense. At their most radical, postcolonial works put the idea of the political itself into crisis, and seek to become untimely with respect to the becoming modern of the political present.

\section{Theorizing the Postcolonial}

But it so happens that when the native hears a speech about Western culture he pulls out his knife-or at least he makes sure it is within reach. The violence with which the supremacy of white values is affirmed and the aggressiveness which has permeated the victory of these values over the ways of life and of thought of the native mean that, in revenge, the native laughs in mockery when Western values are mentioned in front of him. In the colonial context the settler only ends his work of breaking in the native when the latter admits loudly and intelligibly the supremacy of the white man's values. In the period of decolonization, the colonized masses mock at these very values, insult them, and vomit them up.

(FANON, 2004 [1961], p. 8)

Let us meditate on the provocation contained in the epigraph above. In Fanon's words a postcolonial prerogative is violently (re)born. Deep in the anti-colonial struggle from which Fanon wrote, even resistance to the racialized domination of the West is overdetermined, doubly-bound and mediated by multiple estrangements (SPIVAK, 1999; OPONDO, 2021). Fanon's native is estranged, on the one hand, by colonial grids of intelligibility that translate cultural difference as inferiority, as historical backwardness vis-à-vis "Western culture." On the other hand, this colonized subject is internally restrained by an "[...] inferiority complex [that] has been created by the death and burial of [the native's] local cultural originality," as Fanon put it in Black Skin, White Masks (FANON, 1967, p. 18). How does the native respond to this double-bind? They laugh and vomit and then tighten their grip on their knife. The native repulsively expels what the colonizer has force-fed them- "the supremacy of white values" - and this purging becomes the condition of possibility for a decolonial response: the thought-become-act of liberation. Paradoxically, the repetition, the regurgitation, produces something new: a performative critique of modernity in its colonial Western/"universalist" guise. This is simultaneously a political de-centering of the West and the assertion of an historically novel equality.

The Fanon's response makes a mockery of a power that cannot be defeated on its own terms. For the postcolonial theorist Homi Bhabha this move is inextricable from that most foundational, and ambivalent, of colonial strategies of domination: colonial mimicry, or mimesis (BHABHA, 1994, p. 91). Bhabha (1994, p. 86) defines colonial mimicry as "[...] the desire for a reformed, recognizable Other, as a subject of 
a difference that is almost the same, but not quite". This "not quite"/not white becomes a site of intense ambivalence and excessive indeterminacy. For while colonial power imposes an objective of native reformation, expressing a desire for the nonwestern Other to become more like the "civilized" Western Self, the governing imperatives of colonial rule also demand the appearance of the opposite, the reproduction of colonial difference qua racial hierarchy. Ideas and practices of colonial mimicry become inculcated as a form of social control in the justification and maintenance of empire. Ideally, they are to be recited in the hearts and minds of not only every native, but also the colonizers themselves (ORWELL, [1936]) - but only insofar as the status of the latter's "flexible positional superiority" does not become challenged by too close a replication by the former (SAID, 1979, p. 7). In the face of this double-bind Fanon's native vomits in front of the man who demands that they repeat the "truth" of Western superiority. In the discourse of colonial mimicry an alienation is reproduced that furthers the lines of demarcation and distance, partitioning and hierarchically organizing what is commonly intelligible in the encounter, while "that which though known must be kept concealed"- - historical difference-is disavowed as unintelligible, an "[...] impossibility of the Other which repeatedly resists signification" (BHABHA, 1994, p. 89). If there is a postcolonial theoretical discourse, it is to be haunted and estranged by this disavowal of historical difference in the aftermath of the colonial encounter, the impossibility of an equal encounter with the Other and the collective memory of the loss of "local cultural originality."

In this way Bhabha (1994, p. 91) conceptualizes colonial mimesis as a "metonymy of presence," where "[...] mimicry rearticulates presence in terms of its 'otherness', that which it disavows". Yet this space of ambivalence and disavowal simultaneously creates the grounds for a duplicitous enunciation. Mimicry becomes perversely performative: mockery. This is the key insight from Fanon's provocation: the repetition that is also a repudiation, the regurgitation that is simultaneously a purging, an impossible negation of the West's historical violence.

Fanon's words haunt the reader not only in terms of their content but in their very enunciation, where the expressive violence of decolonization becomes an act of mocking dissensus. a mimetic performance in which violence is universalized in its macabre equality — a shock to the senses. ${ }^{3}$ But decolonial violence, Fanon insists, re-

\footnotetext{
${ }^{3}$ Gillo Ponteocorvo's film The Battle of Algiers (1966), in part inspired by Fanon's work, crystallizes in cinematic form the macabre sense of equality qua violence that "re-humanizes" the previously dehumanized Algerians. Rather than glorifying such violence, the film radically equalizes it, making its
} 
humanizes the native subject, because it radically refutes and disorganizes the hierarchical differentiations of humanity that colonialism institutes and incorporates into its grid of cultural and political intelligibility. Thus at the end of Wretched of the Earth, Fanon concludes that it is time to put an end to the "European game": "It is a question of the Third World starting a new history of Man, a history which will have regard to the sometimes prodigious theses which Europe has put forward, but which will also not forget Europe's crimes" (FANON, 2004 [1961], p. 315).

Neither an outright rejection of European qua colonial modernity, nor a call for a return to the pristine precolonial past (not when any link to local cultural originality has been permanently severed), postcolonial critique aims at "[...] achieving a critical perspective on European forms of knowledge" that recognizes both their necessity and inadequacy for thinking through the apparent globalization of political modernity. For Dipesh Chakrabarty (2002, p. 18), maintaining this critical distance becomes "[...] part of the interrogation of their colonial inheritance that postcolonial intellectuals must carry out".

This space of in-betweenness, between modernity and tradition, history and memory, West and non-west, belonging partially to both yet fully to neither, informs the critical stance of significant works of postcolonial theory coming out of South Asia. Partha Chatterjee (1993) takes up this position of critique in his well-known and influential work on the historical emergence of the "nationalist imagination" in colonial India. Locating an irreducible difference between Western accounts of the rise of nationalism, which center the post-Westphalian experience of Europe, and the actual archive of anti-colonial nationalism in colonial India, Chatterjee thinks past the limits imposed on historical thought by the West's "universal" experience of political modernity. In a repartitioning move characteristic of postcolonial thought, Chatterjee (1993) adopts Benedict Anderson's (1983) theory of nationalism as an "imagined community," but splits Anderson's universal model in two: distinguishing an external/ material domain of colonial politics from what he called the inner/spiritual domain of cultural nationalism. Both were to become crucial sites of anti-colonial struggle in India, but they functioned in distinct ways and in different times. Within the former domain, the rule of the modern West had proven itself unassailably superior, so that,

universality give an uncommon sense of equivalence between colonial French and anti-colonial Algerian. More recently, Iciar Bollain's film Even the Rain (2010) achieves a similarly haunting sense of untimely equality in the context of contemporary and colonial Bolivia. A third film, Claire Denis's White Material (2010), I think, attempts to do something similar in the context of "French" west Africa. 
even after independence, a self-conscious mimicry of the West's material institutions of nation-state and economy would become an inescapable part of political modernity in India. But within the so-called spiritual domain an incommensurable difference from the West could be at least partially preserved and projected as "autonomous," or even culturally "sovereign," well before anything like official political sovereignty was achieved for the "nation" as such. It was this latter spiritual domain of cultural difference and "national" uniqueness that sanctified the otherwise problematic mimesis called for in the material domain, so that a strategic balancing of colonial mimicry and anti-colonial mockery became part of the imagining of national identity not just during the independence movement, but in post-independence India as well (MUPPIDI, 2004).

Chatterjee's doubling of the space of the political, to include worlds previously seen as "merely cultural," in the articulation of a specifically anti-colonial nationalism in India, paves the way for someone like Chakrabarty to broaden our concept of political modernity itself:

\begin{abstract}
What distinguished the story of political modernity in India from the usual and comparable narratives of the West was the fact that modern politics in India was not founded on an assumed death of the peasant. The peasant did not have to undergo a historical mutation into the industrial worker in order to become the citizen-subject of the nation... But this fact also meant that the imagination that could properly be called political in the Indian context did not conform to the ideas of thinkers in the West, who theorized the political as a story of human sovereignty in a disenchanted world. (Chakrabarty, 2002, p. 19).
\end{abstract}

For Chatterjee and Chakrabarty, nationalism and political modernity in India exceeded Euro-centric partitions of different spheres of existence, such as those separating the political from the religious or spiritual, or the "modern" citizen from the "premodern" peasant. The intervention of postcolonial theory is to repartition these lines of distinction and demarcation, opening up room for different forms of subjectivity and political sovereignty. In this way, postcolonial theory enacts what Jacques Ranciere calls a "politics of aesthetics," where spaces previously perceived as "pre-political" become political spaces in their own right. As Ranciere argues, 
Politics is first of all the configuration of a space as political, the framing of a specific sphere of experience, the setting of objects posed as "common" and of subjects to whom the capacity is recognized to designate these objects and discuss about them. Politics first is the conflict about the very existence of that sphere of existence, the reality of those common objects and the capacity of those subjects. (RANCIERE, 2006).

The postcolonial prerogative is very much a desire to repartition the lines of distinction and hierarchy that produce colonial domination as cultural and political intelligibility. This holds as much for postcolonial theories of racial difference, nationalism or political modernity as it does for other genres of postcolonial expression, such as literary or filmic texts. These artistic and theoretical works enact a "repartitioning of the sensible,"

[...] that distribution and re-distribution of times and spaces, places and identities, that way of framing and re-framing the visible and the invisible, of telling speech from noise and so on...Politics consist in reconfiguring the partition of the sensible, in bringing on the stage new objects and subjects, in making visible that which was not visible, audible as speaking they who where merely heard as noisy animals. To the extent that it sets up such scenes of dissensus, politics can be characterized as an "aesthetic" activity...there is a "politics of aesthetics." This means that the artistic practices take part in the partition of the perceptible insofar as they suspend the ordinary coordinates of sensory experience and reframe the network of relationships between spaces and times, subjects and objects, the common and the singular. (RANCIERE, 2006)

What Ranciere calls "subjectivation," or the "bringing on the stage new objects and subjects," aptly describes the postcolonial move to provincialize Western models of universality in order to make room for historically different experiences of political modernity. These previously unintelligible histories, spaces and subjects become simultaneously political and aesthetic insofar as they disrupt, repartition and redistribute what we include in "common sense" accounts of the human, the nation, history and the modern world.

In repartitioning and rearranging these "global" structures of apprehension and intelligibility, postcolonial thought participates in "suspending the coordinates of sensory experience" and reframing "the network of relationships" that constitute politics as an aesthetic activity. Hardened distinctions between the political and the cultural, secular and religious, public and private, masculine and feminine, violence 
and order, become unmoored, blurred, doubled, rendered ambivalent and duplicitous. This "productive ambivalence" becomes a critical site of expression in the works of art to be analyzed next, namely Salman Rushdie's 1981 novel Midnight's Children, and Satyajit Ray's 1977 film Shatranj ke Khilari (trans. The Chess Players). Both can be framed as explicitly political works of art, but in what follows, I argue that the politics of these artistic texts emerges in more subtle and complicated ways.

\section{Salman Rushdie's Minor Literature}

Since the subject of Salman Rushdie's novel is the progress of the political juggernaut through the Indian subcontinent-the juggernaut being literally a religious procession taken through the land in celebration, although said to leave behind a wake of destruction-one might expect a dark and somber treatise. It is nothing of the sort. On the contrary, Midnight's Children burgeons with life, with exuberance and fantasy. It has the same effect on the eyes and the ears as a magnificent circus performance-a scene that is brilliant with colour, zest, daredevilry and loud bravado. The language is as full and copious as a flood or fire of tremendous proportions.

(DESAI, 1981)

Language stops being representative in order now to move towards its extremities or its limits.

(DELEUZE and GUATTARI, 1986, p. 23)

English literature has its Indian branch... This literature is also Indian literature. There is no incompatibility here. If history creates complexities, let us not try to simplify them.

(RUSHDIE, 1992, p. 65)

Like Franz Kafka, Salman Rushdie pushes language to its extremes. In Midnight's Children, the discourse of postcolonial Indian nationalism is radically deterritorialized through the pushing of a major language (English) towards its minor intensities. To explore how this is done is the purpose of this section.

Midnight's Children is often positioned, along with other significant works of "Third World" literature, in the category of "national allegory," most famously elaborated by the literary theorist Frederick Jameson (1986). ${ }^{4}$ Thus, the writer Anita Desai in the epigraph above squarely identifies the subject of Midnight's Children: the

\footnotetext{
${ }^{4}$ In this section I refer not only to Jameson's framework of national allegory as a way of interpreting Third World literature, but also to Aijaz Ahmad's well-known critique of the framework. See Ahmad (1987).
} 
political juggernaut that is the Indian nation as it rumbles across the subcontinent from colonial to postcolonial eras. It is not my argument that this national allegorical element is absent from Midnight's Children. Nationalism in its anti-colonial and postcolonial forms is clearly a central part of what the novel is about. But what is more interesting for me than its content is how the novel works, that is, how its content is formed by its expression and vice versa, the pervasive unbalance between the two, their constant movement and oscillation that pushes language to its liminal edge, towards deterritorialization.

Desai writes that the novel "has the same effect on the eyes and the ears as a magnificent circus performance-a scene that is brilliant with colour, zest, daredevilry and loud bravado." Let us pose a few rhetorical questions: how does a novel come to effect the eyes and ears? How do letters and words become colorful and loud? When does expression turn to the ambivalent disavowal of historical difference in the colonial situation in order to reanimate such difference with an alternative potentiality? Expression does this, I argue, by allowing the content to follow from its performative enunciation, rather than responding to some predetermined content. This keeps meaning fluid, open and dynamic. Rather than striving for closure in meaning and stability in form, content follows expression only to capture a contingent moment of meaning, then moves on to capture another intensity, continuously unsettling "naturalized," common sense orders of representation. An "expression machine," to employ the concept of Deleuze and Guattari (1986, p. 28), the work assembles infinite differences that are never fully captured in one interpretation or arrangement of the text, never adequately represented in its language, but are instead traced, then disassembled. The machine then produces images that are often chaotic, contradictory and disruptive. Magically real. These doubled images do not correspond to the content of expression as a sign corresponds to a signified. The relationship is not so simple. But in its complexity, the expressive machine becomes ever more provocative, more artistic and more political.

Rushdie's Midnight's Children tells the story of a first-person narrator, Saleem Sinai, who "[...] at the precise instant of India's arrival at independence [midnight of August 15, 1947], tumbled forth into the world" (1981, p. 3). Due to "the occult tyrannies of those blandly saluting clocks," Saleem and the other one-thousand "midnight children" become "[...] mysteriously handcuffed to history, our destinies indissolubly chained to those of our country." If we momentarily suspend the impulse to see Saleem as merely an allegory of the nation, we notice that the relationship is actually much more direct and unmediated. As Rushdie writes in an introduction to a 
later edition of the novel, the story of Saleem and India is the story of "identical twins," not metaphorical representations (RUSHDIE, 2006). The immodesty of this claim is never understated in the novel, nor is it in Rushdie's later commentaries on the latter, but neither are the stakes involved: "Saleem, ever a striver for meaning, suggested to me that the whole of modern Indian history happened as it did because of him; that history, the life of his nation-twin, was somehow all his fault." The connection is direct and causal, not representative and allegorical.

How then do content and expression function in this novel? If not as representation, which entails a priori forms of content corresponding to intelligible forms of expression, then what? Because their insights on the relationship between content and expression in literature inform my own analysis of Midnight's Children, Deleuze and Guattari's (1986, p. xvii) Kafka: Toward a Minor Literature is integral towards understanding a kind of literature that is "no longer confronted by a 'dialectical' or a 'structural' correspondence between two kinds of form" - content and expression-but instead, "by a machine of expression that is capable of disorganizing its own forms, of disorganizing the forms of content, so as to free up an intense material of expression that is then made of pure content that can no longer be separated from its expression". The following formulation from Deleuze and Guattari relates to Kafka's personal letters. I apply it to a similar relation that is internal to Midnight's Children: between Saleem in the novel's present, and Saleem in recounted history (not that the two are so easily distinguished, as we will see).

For the moment, let us distinguish between a subject of enunciation as the form of expression that writes the letter, and a subject of the statement that is the form of content that the letter is speaking about...It is this duality that Kafka wants to put to a perverse or diabolical use. Instead of the subject of enunciation using the letter to recount his own situation, it is the subject of the statement that will take on a whole movement that has become more fictive or no more than superficial...it transfers movement onto the subject of the statement; it gives the subject of the statement an apparent movement, an unreal movement, that spares the subject of enunciation all need for a real movement...the subject of the statement taking on that real movement that is normally the province of the subject of the enunciation, produces a doubling. (DELEUZE and GUATTARI, 1986, p. 30). 
Resisting readings of Kafka that place content and expression into predeterminate forms, or lock him as author into static positions vis-à-vis the state, capitalism, social, gender or other relations, Deleuze and Guattari read content and expression as moving through the multiple subjectivities of Kafka, as letter writer, as individual, as novelist. If we apply this sort of mobilized, relational subjectivity to the narrator of Midnight's Children, we see how Saleem Sinai's subjectivities morph in their movements across the spaces and times of postcolonial India. On the one hand, we have "the subject of enunciation," the narrator in the present-time of the novel, chronicling his life story, which invariably intersects with significant events and characters in the history of the nation. But crucially, he is interacting with an interlocutor, his "dung-lotus" Padma, whom he promises to marry. Padma serves not only as a witness to the actuality of Saleem's historical present, but also as a conduit for Saleem's imagination and memory, the virtuality of his past. ${ }^{5}$ It is through the telling of his story to Padma that the content, "the subject of the statement" follows the expression in the narrator's enunciatory present. While "the subject of enunciation" sits in his room and writes, the "subject of the statement" moves in and out of different lifeworlds and histories, in and out of India, Pakistan, Bangladesh, through myriad subjectivities, selves, times and spaces. He deals with the travails of colonialism and the postcolonial situation, the violence of ethnic and religious conflict, the successes and failures of democratic politics, his own pre-history, all in the (impossible) pursuit of meaning. His subjectivities are mobilized not only through space and time, but also, by extension, through public and private spheres ("everything that happened, happened because of me" [RUSHDIE, 1981, p. 151]), identity and difference ("I became a citizen of Pakistan" [p. 403]), the thin porous membrane that separates animal from man ("this type is good for nothing but sniffing" [p. 409]), past from present ("I smelled the ghosts of ancient empires in the air" [p. 488]), history from memory ("in my India, Gandhi will continue to die at the wrong time" [p. 190]), reality from imagination ("the children of midnight were also the children of the time. fathered, you understand by history. It can happen. Especially in a country which is itself a sort of dream" [p. 132]). The content, "the subject of the statement" moves through history and nation, changes meaning, becomes alienated, becomes animal, falls apart; while "the subject of enunciation," the expression, is cooped up in a dank, dark room at a condiment factory, immobile, telling his stories to Padma, writing them for us to read. The stories themselves are preserved as pickles in so many jars, but within

\footnotetext{
${ }^{5}$ For more on the idea of virtuality, the past, and non-chronological, perceived time, see Bergson (1991).
} 
each jar is a whole sensory world of content swirling about ("every pickle-jar contains, therefore, the most exalted of possibilities" [RUSHDIE, 1981, p. 529]), always on the move, never fixated, never stable. The stories are in a constantly disassembled relation to "the subject of enunciation," as a machine of expression where expression does not derive from content as in representation, but rather assembles new affective intensities, before disorganizing these and sparking a heterogeneous line of flight. So that the letters and words leap off the page and form a colorful, sonorous circus of expression.

If Rushdie is able to pursue this Kafkaesque mobilization of content and expression it is because Midnight's Children belongs to that genre of literature that becomes inescapably political; it belongs to a minor literature. As Deleuze and Guattari (1986, p. 16-17, 28) put it:

A minor literature doesn't come from a minor language; it is rather that which a minority constructs within a major language $[\ldots]$ in it language is affected with a high coefficient of deterritorialization [...] A major, or established literature follows a vector that goes from content to expression. Since content is presented in a given form of the content, one must find, discover, or see the form of expression that goes with it [...] But a minor, or revolutionary, literature begins by expressing itself and doesn't begin to conceptualize until afterward. Expression must break forms, encourage rupture and new sproutings. When a form is broken, one must reconstruct the content that will necessarily be part of a rupture in the order of things.

Rushdie notes how he and other postcolonial writers have effectively appropriated a major language, English, and pushed it towards a minor usage: "English is by now the world language... What seems to me to be happening is that those peoples who were once colonized by the language are rapidly remaking it, domesticating it...they are carving out large territories for themselves within its frontiers" (RUSHDIE, 1992, p. 64). English becomes deterritorialized so as to push the language to its extremes. In this minoritarian way, English becomes a postcolonial language, "a gift from the British colonizers" which is perversely used to disorganize Britain's hegemony via language: "The English language ceased to be the sole possession of the English some time ago...it's time to admit that the centre cannot hold” (RUSHDIE, 1992, p. 70).

Consider the following passage from Midnight's Children, coming towards the end of the novel and describing the time of the Emergency - the twenty-one month long state of exception from 1975-1977 authorized by Indian Prime Minister Indira 
Gandhi, that saw the curtailment of civil liberties, mass arrests, and the suspension of elections.

The perfumes of emotions and ideas, the odor of how-things-were: all these were and are nosed out by me with ease. When the Constitution was altered to give the Prime Minister well-nigh-absolute powers, I smelled the ghosts of ancient empires in the air...in that city that was littered with the phantoms of Slave Kings and Mughals, of Aurangzeb the merciless and the last, pink conquerors, I inhaled once again the sharp aroma of despotism. It smelled like burning oily rags. (RUSHDIE, 1981, p. 488).

Rushdie's deterritorialization of language is achieved through the literary strategy of magical realism. This strategy is used to render Saleem Sinai's special "midnight gift" in an evocative and sensuous way: namely, the ability to smell things like danger, emotions, and history, and the ability to telepathically communicate with the other children. Through smell and telepathy Sinai is interpellated into a community of sense and sense-making that is the nation-in-formation, the becoming postcolonial nation. But far from the majoritarian concept of national allegory that scholars like Jameson identify with Third World literature, and which others like Ahmad (1987) have critiqued, here the sense of smell serves to deterritorialize nationalism's majoritarian tendency towards ocular-centrism, including a fixation on maps, spatial and ethnic homogeneity. So that, through smell a host of other embodied senses of the past bleed into the present, not through visual metaphor, but through affective capacities which are more direct and less mediated: "[...] the taste of chutney was more than just an echo of that long-ago taste-it was the old taste itself, the very same, with the power of bringing back the past as if it had never been away" (RUSHDIE, 1981, p. 525). Why does India's past haunt Saleem Sinai's senses so directly? And what do the "ghosts of ancient empires" smell like? To render this milieu of sense-making in literature is to push a major language like English to its minor extremes, freeing up perceptive intensities that disorganize the nationalist imagination, mixing past with present, Self and Other, body and space, place and time.

It was in the immediate aftermath of the Emergency period in India that Rushdie wrote Midnight's Children. The turn to absolutism under Gandhi's regime forced a critical reevaluation of the status and state of decolonization. Of course, Fanon had prophesized a crisis of postcolonial legitimacy decades before: "[...] the native bourgeoisie which comes to power uses its class aggressiveness to corner the positions formerly kept for foreigners" (FANON, 2004 [1961], p. 155). When Prime Minister Indira Gandhi's power was threatened by heterogeneous oppositional forces the 
postcolonial state clamped down on civil freedoms in ways eerily reminiscent of its colonial predecessor.

This legacy seems to plague Saleem as he searches for meaning in both himself and his nation-double: "I had in mind something more like a, you know, sort of loose federation of equals, all points of view given free expression [...]" (RUSHDIE, 1981, p. 252). But it is cynicism towards state politics which Saleem espouses most clearly after the Emergency, "[...] a time which damaged reality so badly that nobody ever managed to put it together again" (RUSHDIE, 1981, p. 482). This signals a turning point in the novel, a change in the temporality of events and the tone of the narration. When Saleem writes that "Mother Indira really had it in for me" he is referring both to himself and his juggernaut-twin, as he comes to the painful realization that the convulsing nation that had held so much promise for a decolonial future might fail to meet history's expectations. Compare, for instance, Saleem's triumphant jubilation towards the newness of India after independence_- "[...] a new myth to celebrate [...] a country which would never exist except by the efforts of a phenomenal collective will-except in a dream we all agreed to dream [...] a collective fiction in which anything was possible [...]" (RUSHDIE, 1981, p. 124-125) — to the tired dejection at the end:

[...] the past grew daily more vivid while the present seemed colorless, a thing of no consequence [...] I was no longer interested in anything new [...] the nearly-thirty-one-year-old-myth of freedom is longer what it was. New myths are needed; but that's none of my business. (RUSHDIE, 1981, p. 512-513, 523, 527).

If the nation becomes an allegorical vehicle for expression in Third World literature, what a postcolonial regime of aesthetics presents are other minoritarian mobilizations that render the possibility of the nation as its simultaneous impossibility. This theme of becoming modern while falling apart is extended in Satyajit Ray's magisterial film Shatranj ke Khilari, or, The Chess Players. 


\section{Depths of Field and Historical Difference in Shatranj ke Khilari}

It was the age of Nawab Wajid Ali Shah, and his capital, Lucknow was steeped in subtle shades of decadence and bliss...In fact, the whole kingdom was shackled to sensuality, and in everyone's eyes there was the glow of intoxication caused by the goblet and the wine flask. About the rest of the world, the advances and inventions which knowledge and learning were making, how western powers were capturing areas of land and sea, no one had the slightest idea.

(PREMCHAND, 2005, p. 36)

As an artist, Satyajit Ray (1921-1992) has often been placed into a position of in-betweeness, between region (Bengal) and nation (India), but also between West and East, and between modernity and tradition. In a well-known commentary, Robin Cook, for instance, suggests that "Ray appears to have learnt his art mainly from western cinema," drawing lines of influence between Ray and the works of filmmakers like Renoir, De Sica, Ford, Capra and others (COOK, 1972, p. 12). On the other hand, Darius Cooper (2000, p. 07) argues that a deeper appreciation of Ray's films necessitates a "[...] critical understanding of the social, historical, and cultural traditions of India within which Ray's films predominantly function”. But surely Ray's filmic style, just like his subject matter, is more hybrid and mixed than terms like "Western" and "Indian" suggest. In Shatranj Ke Khilari, arguably Ray's greatest film, it is almost as if he recognizes the limits of "civilizational" binaries in the colonial context, as well as their unavoidable reproduction in treating the history of colonization in South Asia. What seems to concern Ray about these terms is their stubborn inability to adequately treat the nuances of historical difference in ways that do not reproduce the move of disavowal, which translates difference as "lack." Arguably, throughout his filmmaking career, Ray was searching for ways to articulate the productive ambivalence of historical difference in the Indian context. As Cook (1972, p. 15, emphasis mine) goes on to write:

The central unifying thematic preoccupation of all Ray's work to date is change or 'progress': again and again he returns to an investigation of people's attitudes to change, how they cope with it (or fail to cope), the gaps it produces between generations or between people from cultural backgrounds at different stages of development. And the overall attitude to 'progress' is consistently ambivalent: what is created is always balanced (though not negated) by what is destroyed. 
Notwithstanding Cook's historicism, which disavows historical difference by linearizing it through a "stages of development" narrative, so that historical difference becomes temporal backwardness, he nevertheless usefully underlines the productivity of ambivalence in Ray's body of work. Though made some five years after this statement was written, Shatranj ke Khilari, perhaps more than any of Ray's other films, foregrounds the ambivalence of "progress" in the colonial context, while also showing how productive such ambivalence can be.

In large part based on a short story of the same title by the Hindustani writer Munshi Premchand, Shatranj ke Khilari takes place in 1856 in northern India, just one year before the "Great Sepoy Mutiny" (as it was called by the British), or the "First Indian War for Independence" (as it would be renamed by anti-colonial nationalists decades later). This historical moment places the film in an unavoidably political context, even though it never has to directly confront the momentous and violent events of the following year. Instead it tracks a less famous but no less significant sequence of events, which in part trigger the revolt of 1857: the hostile take-over of the Kingdom of Oudh (formerly a part of the Mughal Empire) by the British East Indian Company, and the dethroning of its last king, Wajid Ali Shah. Ray's film explores both sides of the conflictual, yet ultimately non-confrontational encounter.

The film's two major protagonists represent both sides of this historical encounter. On one hand, there is the rationalist world of the British Resident in Lucknow (capital of Oudh), General James Outram, whose task it is to orchestrate the forced transition, despite the existence of a long-standing treaty between the East India Company and the Kingdom assuring the latter's sovereignty. On the other hand, there is the enigmatic ruler King Wajid, who is famous in South Asian history not for his political cunning but for his artistic genius and androgynous style, and is a celebrated poet and the inventor of dance and theater forms that are still practiced and performed in the region today. ${ }^{6}$

The King is presented in an early sequence of the film, but is noticeably introduced, first of all, in his absence, that is, as missing. We see an empty throne, as the film's narrator dryly informs us that, in addition to ruling over Oudh, "the king had other interests too." 7 The first time we actually see Wajid is in the next shot, when the King is dressed up as the Hindu god Krishna, acting in a play, surrounded by a

\footnotetext{
${ }^{6}$ For more on androgyny and gender politics in the film, see Ashis Nandy (1995). For more on Wajid Ali Shah's long lasting artist and cultural influences in northern India see Llewellyn-Jones (2014).

${ }^{7}$ All translated quotes taken from Robinson (1989, p. 16).
} 
"[...] bevy of pretty girls, playing gopinis," or consorts of the god. The narrator informs us that the accompanying music "[...] is a beautiful song composed by Wajid." The camera then cuts to a medium shot of the king leading a Muslim procession down a city street, playing drums, his eyes closed in devout prayer. The penultimate shot in the montage is of the king reclining at night in his harem, once again surrounded by a small army of women. He is being "[...] gently fanned with whisks." Finally, we return to the original shot of the throne, only now with the king present and sitting in his rightful place. The narrator concedes, "Nevertheless, there were times when King Wajid sat on the throne."

In contrast to the opulent and sensual world inhabited by the "aesthete king," full of costumes and art, pleasure and devotion, there are the austere, drab interiors inhabited by the dutiful British Resident. Early in the film we are introduced to the inquisitive General Outram in dialogue with his assistant Captain Weston, who is an Anglo-Indian translator intimately familiar with the Kingdom and its peculiar king. Outram is making an initial inquiry into the fitness of Wajid Ali Shah for administering "responsible government" in Oudh, looking for a pretext for beginning the takeover. Outram goes over the infamous "Sleeman Report" with Weston, which includes, among other things, an "[...] hour-by-hour account of the King's activities dated the $24^{\text {th }}$ of January." The Company-sponsored report reveals that the king prays five times a day, flies kites on the palace roof, tends to his concubines and recites poetry. All this, Outram wryly notes, doesn't leave much time for "the affairs of state." What kind of King does this make him? Outram rhetorically asks his assistant. To which Weston responds, in earnest: "Rather... a special kind, sir...I should think." But such ambivalence will not suffice for Outram, who unleashes his own unequivocal judgement in a tirade: "Special? I would've used a much stronger word than that, Weston. I'd have said a bad king! A frivolous, effeminate, irresponsible, worthless king!"

While the film's narrative set-up frames this colonial encounter in seemingly stereotypical terms - the hyper-rational, masculine Western colonizer versus the inscrutable, effeminate Oriental despot-Ray effectively exceeds this essentialist framework through creative cinematic means. As Ashis Nandy (1995) has argued, Ray as an artist seemingly identifies more with someone like Captain Weston's ambivalence than General Outram's more dismissive attitude towards the King. But one way in which the ambivalence of this identification is rendered productive is through a cinematic strategy that Nandy doesn't discuss. This is the deployment of what Michael Shapiro (2013) calls “aesthetic subjects.” According to Shapiro (2013, p. xiv), aesthetic 
subjects are "characters in texts whose movements and actions (both purposive and non-purposive) map and often alter experiential, politically relevant terrains". In certain artistic texts what the movements and experiences of aesthetic subjects do is generate affects, percepts and concepts "that offer critical forms of uncommon sense" (SHAPIRO, 2013, p. xix). That is, aesthetic subjects are figures who, "[...] through artistic genres, articulate and mobilize thinking" (11). Shapiro's aesthetic subjects are not necessarily the main characters or protagonists of the texts in which they appear, since the latter are normally engaged in pursuing a resolution to whatever conflict frames the narrative. In contrast, less purposive (from the point of view of story/ plot) aesthetic subjects operate in decidedly "non-narrative" spaces and times, in which "untimely" aesthetic experiences and subjectivities become intelligible. ${ }^{8}$ In Shatranj ke Khilari two such aesthetic subjects stand out. The first is the aforementioned Captain Weston, Outram's assistant. What is notable about Weston is not merely his obvious ambivalence towards the King, but his familiarity with both British and Awadhi cultures. ${ }^{9}$ While his post in the Company Army necessitates that he share in Outram's negative judgment of the King, Weston's own aesthetic experience belies this reductive attitude. Earlier in the scene referenced above between Outram and Weston, the former is surprised to learn that, not only does the King write his own poetry, but the poetry is "rather good," according to Weston. A clearly unsettled and dubious Outram then requests Weston to recite some of this poetry, which the latter does in a skilled Urdu cadence that brings the poetry's lyrical form and symbolism to the very surface of the cinematic image. After reciting the King's autobiographical poem in Urdu, Weston translates it for Outram in English:

\footnotetext{
Wound not my bleeding body, Throw flowers gently on my grave.

Though mingled with the earth, I rose up to the skies, People mistook my rising dust for the heavens.
}

Outram is unimpressed, remarking that it "doesn't strike me as a great flight of fancy." To which Weston defensively suggests that, "The poem doesn't translate well,

\footnotetext{
${ }^{8}$ Paul Schrader (2018) calls the creation of such "non-narrative" moments and "distancing" devices a defining part of a new cinematic style which emerged around the world since the 1970s, which he in turn analyzes with Gilles Deleuze's concept of the "time-image," see Deleuze (1989).

${ }_{9}^{9}$ Awadhi culture refers to the culture of the Kingdom of Oudh (also spelled Awadh).
} 
sir." Yet what becomes clear is the cultural (and political) distance that opens up between Outram and Weston in this scene, their spatial proximity notwithstanding. We see two dimensions of the political culture of colonialism as it was operating in India at this time: one was self-consciously "empirical" and distant, reliant on official reports to justify what was already a fait accompli, namely, the annexation of Oudh. This side is equally repulsed and threatened by the difference represented by the King's culture of political rule, it's "local cultural originality.". The other side of colonial culture was more intimately familiar and entangled with this local culture, aware of its complexity and value. Yet it is Outram's point of view that will be historically privileged, and whatever cultural hybridity is represented by Weston's aesthetic appreciation for the King's art, it is in any case unintelligible as properly "political," and thus becomes fit for erasure, or at the very least, made anachronistic in the face of colonial modernity. As Outram puts it at the scene's end: "He can't rule, he has no wish to rule, and therefore he has no business to rule." To which Weston, mindful of retaining his post, must meekly agree.

Later in the film, King Wajid articulates his decidedly anachronistic style of rule to his ministers, in effect defending its authority and difference: "Even after ten years [of rule in Oudh] I can see the love in their eyes. They love my songs. They sing them. Go ask the Resident Sahib: how many Kings of England have written songs? Ask if Queen Victoria has composed songs which her people sing?" (ROBINSON, 1989, p. 41).

In this scene, which is not in the original short story by Premchand, Ray seemingly offers a kind of cinematic apology for the King before the ostensive judgment of "History" (NANDY, 1995). Yet whatever we think his personal judgement, what Ray's film form discloses here is a kind of imagined distance, an intertemporal space, in which it becomes possible to redistribute the intelligibility of the political as such. This lays the ground for an alternative interpretation of historical difference, not as temporal lack but as properly "untimely": a postcolonial critique of colonial modernity. Wajid Ali Shah's defense of his own aesthetic style of rule is in effect a critique of the hypocrisy of "liberal empire," but more perversely, it is also an articulation of the existence of an alternative imagination of political community, one whose untimeliness provides an uncommon sense of political modernity in South Asia in its formative moments.

The aesthetic subjects of Shatranj ke Khilari serve to place us (as viewers) in this untimely space of historical difference. They are figures who seem to stand in-between these colliding cultural and political worlds, which are not merely of different 
geographic origins but represent two juxtaposed temporalities of changing life. Like Weston, who is Outram's assistant, King Wajid's chief assistant, the Prime Minister Ali Naqi Khan, acts as a mediator and translator between the King and the East India Company, and thus is mobilized between these two political and aesthetic spaces. Whereas Weston translates the inscrutable ways of King Wajid for General Outram, Khan translates the desires of British Resident for the King, while also representing the King's decisions to the Resident.

At around the midway point of the film Ray combines one cinematic strategythe mobilization of aesthetic subjects - with another - use of the depth of field shot to juxtapose foreground and background in a single image. To appreciate the power of this specific shot, we need to first set up the scene: Prime Minister Khan has just returned from a meeting with Outram, in which Khan received the decisive message regarding the immanent British takeover of Oudh. Now he must inform King Wajid of these developments, fully aware that this news will displease the King. Yet this news will have to wait. For at the moment the King is being his typical self, that is, fully immersed in his aesthetic and cultural world.

We see King Wajid reclining on a bed of pillows and a plush rug, taking in a skillful dance performance in his music room. Meanwhile Khan must anxiously wait in the wings. The aesthetics and temporality of the performance, including the music, the choreography, the dancer herself, have been playing continuously for a minute and a half, with shots alternating between the talented performers, the fully absorbed aesthete-king, and the agonized expression of Khan. At an artistic level, the performance is just as exquisite as Weston's recitation of poetry in the earlier scene. Like the King, we too become absorbed in the song and dance, the music and the words (about the Hindu god Krishna and his lovers), forgetting for a moment the gravity of the news that awaits the King. Towards the end of the performance, Khan draws close to the King and sits down just a few feet from where the King is, the latter still immersed and enchanted by the dance and music. While we might expect the news of the political annexation to interrupt and supersede the temporality of the song and dance, Ray instead leaves "historical time" in suspense and keeps his camera focused on the aesthetics of the performance, forcing us (and Khan) to subordinate the temporality of British colonial expansion in South Asia with that of the dance performance, and by extension, the temporality of the King's rule. In this scene we are witness to the King, perhaps for the last time, as sovereign in his historically different way. His "local cultural originality," such as it existed in this context, is still intact, 
albeit soon to become extinct. This untimely moment is rendered not directly but indirectly: in the expression on Khan's horrified face, which Ray's camera slowly zooms in on while the song and dance continue to completion.

Once the song and dance number is complete, the King dismisses the performers and others in attendance and finally directs his attention to the Prime Minister, as if just now remembering that his kingdom is at an historical crossroads. Now we cut to our depth of field image. It is a two-shot: with Khan in the foreground, looking sullen and forlorn, and the King in the background, looking entirely at peace, still immersed in the temporality of the musical performance. Holding this frame, we see Khan suddenly bursts into tears. The King consoles his Prime Minister from afar, distanced from him not only by space but by time: "Come now, that is enough." When the crying continues, the King makes a joke that comports with the logic of his aesthetic style of rule: "The Resident Sahib [Gen. Outram] must have been singing ghazals to you. Nothing but poetry and music should bring tears to a man's eyes." Yet when Khan continues sobbing the King gets irritated, forcing Khan to come out with the news. Through muffled sobs, the Prime Minister manages: "Your majesty, you shall no longer wear the crown." The scene ends.

In his work on cinema, the philosopher Gilles Deleuze (1989) notes the critical power of the depth of field shot, which only comes into common use after the middle of the twentieth century, marking a transition into "the modern age" of film. Perhaps no film work augurs this movement into what Ranciere has called "cinematic modernity" more than Orson Welles' Citizen Kane (1941), which explores the relationship between past and present in radically deep focus. Deleuze (1989, p. 107) finds that Welles (and his cinematographer Gregg Toland) invents a "[...] depth of field [...] along a diagonal or gap crossing all planes, making elements from each interact with the rest, and in particular having the background in direct contact with the foreground". Besides such synchronic relations, the deep focus could also establish diachronic resonances. Between these two planes, background and foreground, "[...] the unbridled depth of is of time and no longer of space" (DELEUZE, 1989, p. 108). Thus what we get in the two-shot of the King and his Prime Minister is a time-image of historical difference and political-cultural change.

\section{Some untimely conclusions}

Although Deleuze does not treat any of Ray's films in his books on cinema (or any films from South Asia for that matter-a major oversight), his association of the depth of field shot with what he calls "the time-image" in modern cinema points to a 
specificity in the postcolonial condition that artists like Satyajit Ray or Salman Rushdie (in modern literature) seem particularly interested in exploring. For what the timeimage reveals, whether in the case of historical/costume dramas in film, or in magical realist literature, is a doubled distance, a duplicity, between politics and culture that is specific to the condition of postcoloniality. While Ray's film explores this condition's colonial roots (in the context of northern India), Rushdie's novel seems more interested in examining its ambivalent legacies in molding the life of the nation as an imagined community.

These explorations problematize the ordinary boundaries we might construct between art and theory, culture and politics, ethics and aesthetics.

The postcolonial theorists analyzed in the first part of this essay testify to a similar investment in opening up the experience of the historical present to alternative normative horizons, guided by an uncommon sense of what is modern in changing life. At their best, postcolonial works articulate this untimeliness with respect to the becoming modern of changing milieus, with all of the mutations, scars, and creative hybridities entailed in this process.

Rohan Kalyan é Professor na School of World Studies, Virginia Commonwealth University. E-mail: rohan.kalyan@gmail.com.

\section{Referências}

AHMAD, Aijaz. Jameson's rhetoric of otherness and the "National Allegory". Social text, v. 17, p. 325, 1987. doi: 10.2307/466475

ANDERSON, Benedict. Imagined communities: reflections on the origin and spread of nationalism. New York: Verso, 1983.

BERGSON, Henri. Matter and memory. New York: Zone Books, 1991.

BHABHA, Homi. The location of culture. London: Routledge, 1994.

CHAKRABARTY, Dipesh. Habitations of modernity. Chicago: University of Chicago Press, 2002.

CHAKRABARTY, Dipesh. Provincializing Europe: postcolonial thought and historical difference. Princeton: Princeton University Press, 2000.

CHATTERJEE, Partha. The nation and its fragments. Princeton: Princeton University Press, 1993. COOK, Robin. The Apu trilogy. New York: November Books Ltd., 1972. 
COOPER, Darius. The cinema of Satyajit Ray: between tradition and modernity. Cambridge: Cambridge University Press, 2000.

DELEUZE, Gilles. Cinema 2: the time-image. Minneapolis: University of Minnesota Press, 1989.

DELEUZE, Gilles. Plato and the Simulacrum. (Transl. by Rosalind Krauss). October, v. 27, p. 4556, 1983. doi: $10.2307 / 778495$

DELEUZE, Gilles; GUATTARI, Felix. Kafka: toward a minor literature. Minneapolis: University of Minnesota Press, 1986.

DESAI, Anita. Where cultures clash by night. The Washington Post, March 15, 1981. Accessed online: https://www.washingtonpost.com/archive/entertainment/books/1981/03/15/where-culturesclash-by-night/e3cbbd09-7c32-46de-9275-f880316cb80a/

FANON, Frantz. The wretched of the Earth. New York: Grove Press, 2004.

FANON, Frantz. Black skin, white masks. New York: Grove Press, 1967.

JAMESON, Fredric. Third-world literature in the era of multinational capitalism. Social Text, v. 15, p. 65-88, 1986.

KALYAN, Rohan. Imposition and response: an illustrated interview with Dr. Robbie Shilliam. 2020. (ca $29 \mathrm{~min} 59$ s). Available at: <https://www.youtube.com/watch?v=dPTAIjgIvU8>. Access: Oct. 30, 2021.

KALYAN, Rohan. Neo Delhi and the politics of postcolonial urbanism. London: Routledge, 2017.

LEFEBVRE, Henri. The specificity of the city. In: KOFMAN, Eleonore; LEBAS, Elizabeth (Eds.). Writings on cities. New York: Wiley-Blackwell, 1996.

LLEWELLYN-JONES, Rosie. The last king in India: Wajid Ali Shah, 1822-1887. London: Hurst \& Company, 2014.

MUPPIDI, Himadeep. The politics of the global. Minneapolis: University of Minnesota Press, 2004.

NANDY, Ashis. The savage Freud and other essays on possible and retrievable selves. Princeton: Princeton University Press, 1995.

OPONDO, Samson. Diplomatic para-citations: genre, foreign bodies, and the ethics of co-habitation. London: Rowman \& Littlefield, 2021.

ORWELL, George. Shooting an Elephant. [1936]. Available at: $<$ https://www.orwellfoundation.com/the-orwell-foundation/orwell/essays-and-other-works/shootingan-elephant/>. Accessed: July 22, 2021.

PREMCHAND, Munshi. Selected stories of Premchand (ed. Purnima Mazumdar). New Delhi: Ocean Books, 2005.

RANCIERE, Jacques. The politics of aesthetics. Meta Mute, Sept. 14, 2006. Available at: <https://www.metamute.org/editorial/articles/politics-aesthetics>. Accessed: Oct. 31, 2021.

RAY, Satyajit. Shatanj ke Khilari. 1977.

ROBINSON, Andrew (Ed.). The chess players and other screenplays. London: Faber and Faber, 1989.

RUSHDIE, Salman. The birth pangs of Midnight's Children. Times Online, April 1, 2006. Available at: <https://www.thetimes.co.uk/article/the-birth-pangs-of-midnights-children-zl9b5808m29>. Access: November $1^{\text {st }}, 2021$.

RUSHDIE, Salman. Imaginary Homelands: essays and criticism. New York: Penguin Books, 1992. RUSHDIE, Salman. Midnight's Children. New York: Penguin Books, 1981.

SAID, Edward. Orientalism. New York: Vintage Books, 1979. 
SCHRADER, Paul. Transcendental style in film: Ozu, Bresson, Dreyer. Berkeley: University of California Press, 2018.

SHAPIRO, Michael. The political sublime. Durham: Duke University Press, 2018.

SHAPIRO, Michael. Studies in trans-disciplinary method: after the aesthetic turn. London: Routledge, 2013.

SPIVAK, Gayatri. Critique of postcolonial reason. Cambridge: Harvard University Press, 1999.

Texto recebido em 28 de outubro de 2021. Aprovado em 15 de novembro de 2021. 